\title{
IMPLEMENTASI TENAGA PENDIDIK PADA KURIKULUM 2013 SEKOLAH MENENGAH KEJURUAN
}

\author{
Bahri Johan Tarigan(Pendidikan Teknik Mesin) \\ Universitas Negeri Padang \\ *Corresponding author, e-mail:bahritarigan03@gmail.com*
}

\begin{abstract}
Abstrak
Pendidikan kejuruan di masa ini dihadapkan pada berbagai tantangan yang makin berat dan perubahan yang sangat cepat. Kurikulum adalah perangkat mata pelajaran dan program pendidikan yang diberikan oleh suatu lembaga penyelenggara pendidikan yang berisi rancangan pelajaran yang akan diberikan kepada peserta pelajar di dalam satu periode jenjang pendidikan.namun dalam pelaksanya terdapat beberapa beberapa masalah yang tidak sesuai dengan tujuan pendidikan yang mana Tujuan pendidikan kejuruan adalah mempersiapkan peserta didik sebagai calon tenaga kerja dan mengembangkan eksistensi para peserta didik, untuk kepentingan peserta didik, masyarakat, bangsa dan negara. Kata Kunci: implementasi, kurikulum 2013, serta pelaksanaan nya
\end{abstract}

\section{A. LATAR BELAKANG}

Pada Pasal 3 UU No. 20 Tahun 2003 tentang Sistem Pendidikan Nasional menyatakan tujuan nasional adalah berkembangnya potensi peserta didik agar menjadi manusia yang beriman dan bertakwa kepada Tuhan Yang Maha Esa, berakhlak mulia, sehat, berilmu, cakap, kreatif, mandiri, dan menjadi warga negara yang demokratis serta bertanggung jawab. Tujuan itu harus dapat diwujudkan melalui penyelenggaraan pendidikan yang berpedoman pada kurikulum.

Sejarah kurikulum Indonesia yang dimulai tahun 1945 telah mengalami banyak perubahan. Tahun 1947 kurikulum rencana pelajaran dirinci dalam Rencana Pelajaran Terurai, 1964 Rencana Pendidikan Sekolah Dasar, 1968 Kurikulum Sekolah Dasar, 1973 Kurikulum Proyek Perintis Sekolah Pembangunan (PPSP), 1975 Kurikulum Sekolah Dasar, 1984 Kurikulum 1984, 1994 Kurikulum 1994, 1997 revisi Kurikulum 1994, 2004 Kurikulum Berbasis Kompetensi (KBK), 2006 Kurikulum Tingkat Satuan Pendidikan (KTSP) (Soleh Hidayat, 2013: 1).

Menurut E. Mulyasa (2013: 60-61) penyusunan kurikulum 2013 yang menitikberatkan pada penyederhanaan dan pembelajaran tematik-integratif dikarenakan adanya beberapa kelemahan yang terdapat dalam KTSP, yaitu sebagai berikut: 1) isi dan pesan-pesan kurikulum masih terlalu padat, yang ditunjukkan dengan banyaknya mata pelajaran dan banyak materi yang tingkat kesukarannya melampaui tingkat perkembangan usia anak, 2) kurikulum belum mengembangkan kompetensi secara utuh sesuai dengan visi, misi, dan tujuan pendidikan nasional, 3) kompetensi yang dikembangkan lebih 
didominasi oleh aspek pengetahuan, belum sepenuhnya menggambarkan pribadi peserta didik dalam pengetahuan, keterampilan, dan sikap, 4) berbagai kompetensi yang diperlukan sesuai dengan perkembangan masyarakat, seperti pendidikan karakter, kesadaran lingkungan, pendekatan dan metode pembelajaran konstruktifistik, keseimbangan soft skills dan hard skills, serta jiwa kewirausahaan, belum terakomodasi di dalam kurikulum, 5) kurikulum belum peka dan tanggap terhadap berbagai perubahan sosial yang terjadi pada tingkat lokal, nasional, maupun global, 6) standar proses pembelajaran belum menggambarkan urutan pembelajaran yang rinci sehingga membuka peluang penafsiran yang beraneka ragam dan berujung pada pembelajaran yang berpusat pada guru, 7) penilaian belum menggunakan standar penilaian berbasis kompetensi, serta belum tegas memberikan layanan remediasi dan pengayaan secara berkala.

Guru memegang peranan penting dalam keberhasilan implementasi Kurikulum 2013. Kemampuan guru dalam melaksanakan kegiatan pembelajaran sangat berpengaruh dalam pelaksanaan kurikulum. Kurangnya kemampuan guru dalam pelaksanaan pembelajaran dapat menyebabkan kegagalan dalam implementasi kurikulum.

Penilaian hasil belajar juga merupakan hal yang penting dalam implementasi kurikulum. Pelaksanakan penilaian oleh guru dengan mengikuti standar penilaian yang ditetapkan oleh pemerintah. Dalam Permendiknas No 66 Tahun 2013 dijelaskan bahwa Standar Penilaian Pendidikan adalah kriteria mengenai mekanisme, prosedur, dan instrumen penilaian hasil belajar peserta didik. Penilaian pendidikan sebagai proses pengumpulan dan pengolahan informasi untuk mengukur pencapaian hasil belajar peserta didik. Deden Cahaya Kusuma (2013) dalam penelitiannya menyimpulkan bahwa rancangan kurikulum yang terdapat pada Bahan Uji Publik Kurikulum 2013 memiliki komponen-komponen pengembangan kurikulum yang terdiri dari komponen tujuan, komponen isi, komponen metode, dan komponen evaluasi. Untuk komponen tujuan, isi, dan metode sudah dapat dikatakan baik, namun uuntuk komponen evaluasi masih belum berperan secara maksimal. Hal ini dapat terlihat dari beberapa permasalahan kurikulum 2006 yang masih belum diselesaikan.

\section{B. METODE PENULISAN}

Penelitian ini menggunakan pendekatan penelitian kualitatif dengan jenis penelitian desain, penelitian deskriptif. Penelitian ini merupakan prosedur penelitian yang akan menghasilkan data deskriptif yaitu berupa kalimat tertulis dari beberapa sumber artikel. Teknik pengumpulan data dengan telaah kepustakaan dimana dalam pembuatan artikel ini dikutip dari artikel yang telah dipublikasi pada jurnal atau prosiding ilmiah. 


\section{PERMASALAHAN}

Terdapat beberapa hal yang sangat mempengaruhi berjalannya implementasi kurikulum utamanya pembelajaran di SMK Yaitu sbb:

1.Sarana dan prasarana pendukung proses pembelajaran, terutama buku pelajaran yang belum cukup dari pemerintah

2.Guru belum sepenuhnya paham tentang Kurikulum 2013.

3.Guru masih bingung dengan penilaian yang sangat banyak dalam Kurikulum 2013, terutama dalam menilai aspek sikap.

4.Adanya guru yang belum menguasai IT, padahal untuk melaporkan hasil penilaian dibutuhkan penguasaan IT.

5. Dana yang minim dari sekolah untuk mengembangkan potensi peserta didik, sehingga pelaksanaan Kurikulum 2013 terhambat.

6.Kurikulum 2013 menghabiskan banyak waktu jika dilaksanakan secara keseluruhan.

\section{D.PEMBAHASAN}

Kurikulum 2013 merupakan kurikulum operasional yang dilaksanakan di masing-masing satuan pendidikan. Namun karena adanya pergantian Menteri Pendidikan maka dibuat keputusan tentang Kurikulum 2013. Jika sekolah belum menerapkan Kurikulum 2013 selama 3 semester maka proses pembelajaran kembali ke Kurikulum Tingkat Satuan Pendidikan, namun untuk sekolah yang telah menerapkan Kurikulum 2013 selama 3 semester maka Kurikulum 2013 tetap dilanjutkan di sekolah itu. Implementasi Kurikulum 2013 dalam pelaksanaan pembelajaran pada kelas $\mathrm{X}$ belum sepenuhnya lancar. Pada pembelajaranya belum seluruhnya berjalan sesuai RPP. Dalam kegiatan pendahuluan guru terkadang tidak menyampaikan apersepsi dan tujuan pembelajaran. Dalam kegiatan inti yaitu melaksanakan pembelajaran sainstifik $(5 \mathrm{M})$ yaitu mengamati, menanya, mencoba, menalar dan mengkomunikasikan belum sepenuhnya berjalan lancar.

Pada saat menanya siswa cenderung malu dan kurang percaya diri untuk menanyakan materi yang belum dipahami. Hanya siswa tertentu yang tidak malu untuk bertanya. Guru berupaya untuk membuat siswa menanyakan materi yang belum dipahami dengan cara berkeliling dan melihat seberapa siswa itu mampu memahami materi. Guru memberikan bantuan kepada siswa yang mengalami kesulitan dalam memahami materi.

Pada saat mencoba pun terkadang siswa kurang percaya diri sehingga meniru jawaban dari temannya yang telah selesai mengerjakan. Guru memberikan arahan bahwa jawaban salah tidak masalah yang penting sudah 
mencoba mengerjakan, selain itu nanti pada akhir pembelajaran jawaban juga akan dikoreksi bersama.

Pada saat mengkomunikasikan siswa juga cenderung malu dan kurang percaya diri untuk mempresentasikan hasilnya. Siswa masih merasa takut salah. Guru berulang kali menekankan salah tidak menjadi masalah, karena dari kesalahan itu siswa menjadi lebih mengerti materi. Pada akhir pembelajaran hasil dari siswa juga akan dikoreksi dan disimpulkan bersama guru. Keberanian adalah hal utama yang diperlukan pada proses mengkomunikasikan ini.

Dalam kegiatan penutup terkadang guru lupa untuk menyimpulkan materi yang telah dipelajari. Guru juga terkadang lupa untuk memberikan tugas atau PR kepada siswa untuk dikerjakan di rumah agar siswa dapat lebih memahami materi. Kemampuan peserta didik dalam bidang pengetahuan yang berbeda-beda menjadi kendala dalam pelaksanaan Kurikulum 2013. Siswa yang aktif dalam kegiatan pembelajaran hanya itu-itu saja. Sulit untuk membuat peserta didik yang lain untuk aktif dan mampu berpikir ilmiah, akibatnya guru harus menjelaskan materi pelajaran.

Dalam Kurikulum 2013 diharapkan peserta didik aktif dan mampu berpikir ilmiah dalam proses pembelajaran. Untuk membuat siswa aktif dalam pembelajaran matematika guru menggunakan metode ceramah dan diskusi, serta model pembelajaran Problem Based Learning, Discovery Learning dan Project Basic Learning. Guru juga menggunakan model pembelajaran lain seperti Problem Solving dan Jigsaw.

Kendala-kendala yang dialami dalam pelaksanaan Kurikulum 2013 adalah sebagai berikut:

1. Sarana dan prasarana pendukung proses pembelajaran, terutama buku pelajaran yang belum cukup dari pemerintah

2. Guru belum sepenuhnya paham tentang Kurikulum 2013.

3. Guru masih bingung dengan penilaian yang sangat banyak dalam Kurikulum 2013, terutama dalam menilai aspek sikap.

4. Adanya guru yang belum menguasai IT, padahal untuk melaporkan hasil penilaian dibutuhkan penguasaan IT.

5. Dana yang minim dari sekolah untuk mengembangkan potensi peserta didik, sehingga pelaksanaan Kurikulum 2013 terhambat.

6. Kurikulum 2013 menghabiskan banyak waktu jika dilaksanakan secara keseluruhan.

Pada pembelajaran praktek penilaian keberhasilan peserta didik dilihat dari keaktifan dan kemampuan peserta didik untuk memahami materi yang telah diajarkan. Selain itu peserta didik juga harus menunjukkan sikap yang baik dalam kegiatan pembelajaran.

Penilaian dari aspek sikap atau afektif dilihat dari sikap peserta didik dalam proses pembelajaran. Dalam aspek sikap penilaian dilakukan menggunakan angket diisi oleh diri sendiri, teman sejawat dan guru. Nilai 
akhir dari aspek sikap ini merupakan nilai dominan yang didapat oleh peserta didik.

Penilaian dari aspek pengetahuan atau kognitif dilihat dari kemampuan peserta untuk menguasai materi pelajaran. Penilaian dari aspek pengetahuan ini bisa dilakukan dari pemberian soal kepada peserta didik, ulangan harian, UTS dan UAS. Nilai akhir dari aspek pengetahuan adalah nilai yang paling baik dari semua nilai pengetahuan dalam satu mata pelajaran.

Penilaian dari aspek keterampilan atau psikomotor bisa dilihat dari keterampilan siswa untuk menjawab persoalan yang diberikan oleh guru. Dalam penilaian keterampilan guru memperhatikan sejauh mana siswa memiliki keterampilan untuk menyelesaikan suatu persoalan. Nilai akhir dari aspek keterampilan adalah nilai yang paling baik dari semua nilai keterampilan dalam satu mata pelajaran. Remidial dilakukan jika hasil nilai ulangan harian, Ulangan Tengah Semester (UTS) dan Ulangan Akhir Semester (UAS) belum mencapai KKM. Remedial biasanya dilakukan setelah pembagian nilai hasil ulangan harian, UTS dan UAS. Remedial seharusnya dilakukan dengan mengulang proses pembelajaran agar peserta didik dapat memahami materi dengan baik dan selanjutnya memberi soal untuk dikerjakan. Kendala yang dialami untuk penilaian dalam Kurikulum 2013 ini adalah keterkaitan aspek sikap, pengetahuan dan keterampilan yang semuanya harus mencapai KKM. Apabila salah satu aspek tidak mencapai KKM maka peserta didik tidak dapat naik kelas

Dalam penilaian aspek pengetahuan dan keterampilan pun guru mengalami kendala, karena nilai terakhir yang diambil adalah nilai yang paling baik. Padahal untuk mengetahui kemampuan peserta didik tidak cukup hanya dengan melihat nilai yang paling baik.Untuk meminimalkan kendala yang dihadapi dalam penilaian aspek sikap, guru biasanya memberikan memberikan arahan kepada siswa untuk selalu bersikap baik dalam proses pembelajaran dikarenakan nilai sikap menentukan siswa tersebut naik kelas atau tidak naik kelas. Untuk meminimalkan kendala yang dihadapi dalam penilaian aspek pengetahuan dan keterampilan guru berupaya memberikan permasalahan atau ulangan supaya siswa dapat memiliki nilai maksimal dan dilakukan remedial untuk siswa yang belum mencapai KKM.

Terdapat beberapa kendala.dan adapun Kekurangan dan Kelebihan Kurikulum 2013 adalah Kurikulum 2013 merupakan suatu program di dalam pendidikan yang dirancang untuk kemajuan pendidikan di masa depan. Selayaknya suatu karya, kurikulum ini tidak luput dari cacat atau memiliki kekurangan di dalam pelaksanaannya.

Kekurangan Kurikulum 2013 menurut saya ialah:

1.Guru tidak dilibatkan langsung dalam pengembangan Kurikulum 2013 Guru juga tidak dilibatkan langsung dalam proses pengembangan 
Kurikulum 2013. Pemerintah melihat seolah-olah guru dan siswa mempunyai kapasitas yang sama.

2.Pemahaman Guru yang kurang akibat pelatihan belum optimal Sosialisasi yang belum menyeluruh dan pengembangannya yang tidak melibatkan guru menyebabkan kebingungan di kalangan para pendidik. Guru sebagai tenaga pendidik dikatakan diberi kemudahan yang besar dalam pelaksanaan pembelajaran, namun penyuluhan yang kurang dan pelatihan yang belum optimal menyebabkan hambatan tersendiri bagi guru yang harus menyiapkan beberapa mata pelajaran untuk diajarkan sekaligus. Guru kebingungan mengajarkan materi dan menyajikan LKS karena semua materi untuk satu hari dipadatkan di dalam satu pembelajaran.

3.Ujian masih menjadi permasalahan Ujian yang diadakan pada tiap pertengahan semester (UTS), dan akhir semester (UAS) menjadi pro dan kontra di kalangan tenaga pendidik dikarenakan evaluasi telah tercantum di akhir setiap tema dan di setiap akhir pembelajaran telah dimasukkan Lembar Kerja Siswa di dalamnya. Sehingga dengan adanya berbagai penilaian masih menjadi pertanyaan mengenai keputusan pengadaan UTS dan UAS.

4.Buku-buku belum terdistribusikan dengan baik Buku Paket berupa Buku Guru dan Buku Siswa yang disusun oleh Kemendikbud belum terdistribusi di seluruh wilayah Indonesia.

5.Kurangnya koordinasi antara pemerintah kabupaten/kota dengan pemerintah pusat Kurangnya koordinasi antara pemerintah daerah dan pemerintah pusat menyebabkan pelaksanaan Kurikulum 2013 terhambat. Sebagian daerah belum menerapkan meski tersedia tenaga pendidik terlatih untuk penerapan Kurikulum 2013.

\section{Kelebihan Kurikulum 2013 sbb:}

Di dalam Kurikulum 2013 tidak hanya kekurangan akan tetapi terdapat berbagai kelebihan yang melengkapi kurikulum sebelumnya. Dengan kelebihan-kelebihan yang ada, diharapkan kurikulum ini dapat mewujudkan generasi emas Indonesia 2045 (Gold Generation). Kelebihan Kurikulum 2013 menurut pengamatan saya ialah sebagai berikut.

1.Pemerataan penggunaan Buku Paket (Buku Guru dan Buku Siswa) di seluruh Indonesia Kemendikbud menyediakan Buku Paket yang sama untuk seluruh daerah di Indonesia untuk menyamaratakan pendidikan agar tidak adanya kesenjangan antara pusat dan daerah maupun daerah satu dan lainnya. 
2.Penggunaan tematik-integratif atau tematik terpadu di dalam pembelajaran Kegiatan pembelajaran Kurikulum 2013 menggunakan tematik-terpadu. Setiap pembelajaran dilakukan berdasarkan tema dan subtema yang telah berisi beberapa mata pelajaran. Beberapa mata pelajaran ini diajarkan secara bersamaan agar menciptakan cara berpikir terpadu pada siswa sehingga siswa dapat mengaitkan dan menemukan hubungan antar mata pelajaran.

3.Memudahkan guru dalam kegiatan pembelajaran Buku Guru disusun berdasarkan Kompetensi Inti, Kompetensi Dasar, tersedia tujuan pembelajaran, media yang digunakan, langkah-langkah kegiatan, dan penilaian yang memudahkan guru dalam menyusun Silabus dan RPP.

4.Meningkatkan kreatifitas serta inovasi siswa dan guru Pembelajaran tematik-terpadu menuntut siswa dan guru untuk selalu berinovasi dan mengolah kreatifitas di dalam prosesnya dikarenakan setiap mata pelajaran berkaitan dengan mata pelajaran lainnya. Pendekatan scientific menjadi kunci Kurikulum 2013 ini.

5.Isi buku yang padat dan terstruktur Materi di dalam buku yang telah dipadatkan dan disusun secara terstruktu. Siswa tidak perlu membawa berbagai buku sesuai mata pelajaran setiap harinya karena semua mata pelajaran telah dipadatkan di dalam satu buku tema.

6.Mengutamakan pengembangan sikap, karakter, dan keterampilan Dalam rangka pendidikan moral dan karakter, aspek penilaian dalam setiap pembelajaran menekankan pada penilaian sikap dan karakter siswa. Keterampilan juga menjadi aspek penting yang disejajarkan dengan pengetahuan. Hal ini dalam tujuan membentuk generasi Indonesia yang mulia akhlak dan karakternya, serta terampil dan berilmu.

\section{D.KESIMPULAN}

Implementasi Kurikulum 2013 dalam pelaksanaan pembelajaran akan berjalan dengan baik. Tentunya dengan terpenuhi segala aspekmulai dari segi pasilitas ,pengajar maupun dukungan dari pemerintah

Namun dalam pelaksanaannya masih terdapat 1 kendala utama dalam pelaksanan kurikulum 2013. Kendala utama yang dialami dalam pelaksanaan Kurikulum 2013 adalah guru belum sepenuhnya paham tentang Kurikulum 2013. 


\section{DAFTAR PUSTAKA}

Hidayat, Sholeh. 2013. Pengembangan Kurikulum Baru. Bandung: Remaja Rosda Karya

Kusuma, Deden Cahaya. 2013. "Analisis Komponen-Komponen Pengembangan Kurikulum 2013 pada Bahan Uji Publik Kurikulum 2013”, Jurnal Analisis

Komponen-Komponen Pengembangan Kurikulum 2013, 1-21

Mulyasa, E. 2013. Pengembangan dan Implementasi Kurikulum 2013: Perubahan dan Pengembangan Kurikulum 2013 Merupakan Persoalan Penting dan Genting. Bandung: Remaja Rosdakarya

Ningrum,T.A. 2019.RENCANA STRATEGI SMK NEGERI 1 RANAH PESIIR,Jurnal

Prastowo, Andi. 2011. Metode Penelitian Kualitatif dalam Perspektif Rancangan Penelitian. Yogyakarta: Ar Ruzz Media

Undang-Undang Nomor 20 Tahun 2003 tentang Sistem Pendidikan Nasional 
